\title{
The relationship between servant leadership and employee empowerment, commitment, trust and innovative behaviour: A project management perspective
}

\begin{tabular}{|c|c|}
\hline \multicolumn{2}{|c|}{$\begin{array}{l}\text { Authors: } \\
\text { Camilla L. Krog }{ }^{1} \\
\text { Krishna Govender }{ }^{1,2}\end{array}$} \\
\hline \multicolumn{2}{|c|}{$\begin{array}{l}\text { Affiliations: } \\
\text { 'Regenesys Business School, } \\
\text { Johannesburg, South Africa }\end{array}$} \\
\hline \multicolumn{2}{|c|}{$\begin{array}{l}{ }^{2} \text { School of Management, IT } \\
\text { and Governance, University } \\
\text { of KwaZulu-Natal, } \\
\text { South Africa }\end{array}$} \\
\hline \multicolumn{2}{|c|}{$\begin{array}{l}\text { Correspondence to: } \\
\text { Krishna Govender }\end{array}$} \\
\hline \multicolumn{2}{|c|}{$\begin{array}{l}\text { Email: } \\
\text { krishnag@regenesys.co.za }\end{array}$} \\
\hline \multicolumn{2}{|c|}{$\begin{array}{l}\text { Postal address: } \\
\text { Postnet Suite \#71, Pr } \\
\text { Bag X9976, Sandton } \\
2146 \text {, South Africa }\end{array}$} \\
\hline \multicolumn{2}{|c|}{$\begin{array}{l}\text { Dates: } \\
\text { Received: } 11 \text { May } 2015 \\
\text { Accepted: } 22 \text { July } 2015 \\
\text { Published: } 16 \text { Oct. } 2015\end{array}$} \\
\hline \multicolumn{2}{|c|}{$\begin{array}{l}\text { How to cite this article: } \\
\text { Krog, C.L., \& Govender, K. } \\
\text { (2015). The relationship } \\
\text { between servant } \\
\text { leadership and employee } \\
\text { empowerment, commitment, } \\
\text { trust and innovative } \\
\text { behaviour: A project } \\
\text { management perspective. SA } \\
\text { Journal of Human Resource } \\
\text { Management/SA Tydskrif vir } \\
\text { Menslikehulpbronbestuur, } \\
\text { 13(1), Art. \#712, } 12 \text { pages. } \\
\text { http://dx.doi.org/10.4102/ } \\
\text { sajhrm.v13i1.712 }\end{array}$} \\
\hline \multicolumn{2}{|c|}{$\begin{array}{l}\text { Copyright: } \\
\text { (C) 2015. The Authors. } \\
\text { Licensee: AOSIS } \\
\text { OpenJournals. This work is } \\
\text { licensed under the Creative } \\
\text { Commons Attribution } \\
\text { License. }\end{array}$} \\
\hline \multicolumn{2}{|l|}{ Read online: } \\
\hline 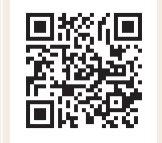 & $\begin{array}{l}\text { Scan this QR } \\
\text { code with your } \\
\text { smart phone or } \\
\text { mobile device } \\
\text { to read online. }\end{array}$ \\
\hline
\end{tabular}

Orientation: Understanding the relationship between a project sponsor's servant leadership traits and employee commitment, trust and innovative behaviour.

Research purpose: This study aimed to understand the relationship, if any, between a project sponsor's servant leadership traits of altruistic calling, emotional healing, wisdom, persuasive mapping and organisational stewardship and a project team's empowerment, commitment, trust and innovative behaviour.

Motivation of the study: Most project leadership studies focus on understanding the role and power position of the project manager, with very little research being dedicated to understanding the effect the leadership style has on the project team and project success.

Research approach: A survey was conducted amongst a non-probability sample of 48 project team members from amongst a population of 257, comprising project managers, business analysts and IT staff of a medium sized fleet management organisation that is in the process of implementing an entirely new enterprise resource planning system.

Main findings: Through inferential statistical analysis, using structural equation modelling and path analysis, it was determined that persuasive mapping has the strongest impact on employee innovative behaviour, followed by employee commitment and trust via the mediator of employee perceived empowerment. Wisdom and organisational stewardship had a negative impact on employee perceived empowerment.

Practical/managerial implications: Project sponsors need to exhibit persuasive mapping, altruistic calling and emotional healing traits due to the significant influence that these have on employee innovative behaviour, commitment and trust, albeit through their perceived empowerment.

Contribution/value-add: This study contributes to knowledge of leadership, more especially servant leadership and its significance in project management, which knowledge may contribute to project success.

\section{Introduction}

Leadership has remained a fascination through the ages, possibly because of its mysterious nature and also because it touches everyone's lives (Yukl, 2013, p. 17). Within the project management field, leadership is recognised as a key practical skill; however, what is more interesting is the extent to which traditional leadership models and theories are able to successfully capture their effectiveness within a project environment (Clarke, 2012, pp. 128129). Tannenbaum and Schmidt (1973, as cited in Clarke, 2012, p. 197) argue that leadership style offers a means to categorise the different leaders' behaviours within the current context and provides the mechanism to establish the manner in which a project manager would behave towards the project team.

Most studies focus on understanding the roles and power position of the project manager (Clarke, 2012, p. 128), with very little research being dedicated to understanding the effect of the leadership style on the project team. With the rapid expansion of organisations utilising projects as an everyday form within the workplace (Jessen, 2002, as cited in Clarke, 2012, p. 128) it is important to understand the relationship between the project sponsor's leadership style and the project team's 'outcomes'. 
Although Greenleaf's (1970) servant leadership essay sparked much interest, resulting in many articles being written supporting it as a fresh approach to leadership (Sipe \& Frick, 2009, as cited by Hayden, 2011, p. 3) it is only in the last 5 years, that it has been possible to measure the servant leadership dimensions within a leader (Hayden, 2011 , p. 4). This however only addresses half of the problem, as the ability to measure follower outcomes is also imperative (Greenleaf, 1970, as cited in Hayden, 2011, p. 2). Furthermore, an understanding of followers' 'outcomes' goes beyond those elements identified by Greenleaf , namely, healthier, wiser, freer, autonomous and becoming servant leaders themselves, and requires further investigation. Moreover, although studies have focused on the servant leader in a general organisational environment, very little attention has been given to understanding the servant leader in a project environment, especially the role of a project sponsor. Furthermore, little or no attention has been given to understanding the optimal leadership profile of a project sponsor and even less to understanding the influence that the project sponsor's leadership style has on the individual outcomes within a project team.

In light of the above, the focus of this article is to understand the influence, if any, that a project sponsor's servant leadership traits of altruistic calling, emotional healing, wisdom, persuasive mapping and organisational stewardship have on a project team's 'outcomes', which, for the purposes of this article are defined as: employee empowerment, commitment, trust and innovative behaviour.

\section{Literature review Leadership}

Yukl (2013, p. 26) argues that a leader's characteristics have been the dominant focus of leadership studies, with specific emphasis on one or all of the following characteristics: trait, behaviour, or power. Research in the field of, inter alia, contingency or situational theory states that the ideal leadership style is dependent on the situation, the follower and the leader (Hannay, 2009, p. 2). This approach emphasises the importance of contextual factors that influence leadership processes, the major variables being the type of work to be carried out, the type of organisation and the external environment (Yukl, 2013, p. 29). Emerging leadership theories suggest that the true power of a leader is no longer linked to the leader's position within the organisation, but rather to transforming the organisation and its workers (Burns, 1978 as cited by Stone \& Patterson, 2005, p. 7). Today's leadership theory studies have evolved and extend into focusing on the ethical leader, which encompasses transforming, servant, authentic and spiritual leadership styles (Yukl, 2013, p. 335).

\section{Project leadership}

As a result of the environmental challenges, projects are proving to be an effective vehicle for organisations to be flexible and adaptable to their changing environments and are therefore able to assist organisations achieve their strategy, in the development of new products and services and to continually improve the organisation and its product and service offering (Winter et al., 2006, as cited by Leyva \& Matović, 2011, p. 1). Hauschildt et al. (2000, as cited by Thompson, 2010, p. 6) identified that both technical components and organisational and human aspects are the challenges that affect the success of a project, and they established that the technical components contributed to $50 \%$ of the challenge, with the remaining $50 \%$ being organisational and human aspects, with leadership being the major factor.

Leadership in a project team has yet to receive the attention that it deserves (Clarke, 2012, p. 128) and has primarily focused on trying to identify the optimal leadership profiles of a project manager for different project types. According to Riaz, Masood and Mohammad (2013, p. 99) in order for a project to be a success, it is essential that the right leadership and management skills, knowledge, expertise and characteristics are present in order for the right decisions to be made at the right time, with the right resources allocated to the right place. Project leadership is ultimately responsible for defining a clear and understandable project mission outlining the project outcomes, which can be measured (Anantatmula, 2010, p. 19). Although there is no definitive leadership style that is preferred above others as the ideal style when leading projects (Anantatmula, 2010, p. 14), Thompson (2010) has recognised servant leadership as being a model that may assist in overcoming many of the challenges a leader may face on a project. In order for a project to be a success it relies heavily on effective and efficient activities performed by individuals at three levels, namely the project sponsor, project managers and project team members (Kilkelly, 2011, p. 4). Project teams are widely used in organisations that undertake research and development, innovation and product development, and are relatively easy to study as they have clearly defined tasks, dedicated resources with a fairly stable membership and leadership structure (Rickards \& Moger, 2000, p. 273). It is the responsibility of the project's leadership, in this case the project sponsor, to ensure that the project team forms a cohesive unit, which can only be achieved through the continual nurturing of the team in order to cultivate a team that has its own unique identity and personality, whilst remaining focused on its objectives and goals. According to Redick, Reyna, Schaffer and Toomey (2014, p. 29), one of the most challenging tasks of the leader or project sponsor is to get the project team to work together as a team, since without a cohesive team, the project could be in jeopardy of being unsuccessful.

The concern for societies is on leadership that is focused on employee well-being (Van Dierendonck, 2010, p. 1228); servant leadership emerged as a leadership theory that has been linked to ethics, virtues and morality (Parris \& Peachey, 2013, p. 378). Graham (1991, as cited by Van Dierendonck, 2010 , p. 2) states that servant leadership may be of particular relevance in this era due to its focus on social responsibility. 


\section{Servant leadership}

The concept 'servant leadership' was coined by Greenleaf (1970, as cited by Yukl, 2013, p. 336) who defined it as an individual's desire to serve others. Servant leadership can be defined as the manner in which a servant leader goes about influencing their followers; a servant leader is also the leader who actively understands and practises behaviour that places the good of those they lead over their own selfinterest: the emphasis is placed on developing followers rather than the glorification of the leader (Hale \& Fields, 2007, as cited by Walumbwa, Hartnell \& Oke, 2010, p. 517). Whilst researchers acknowledge that volumes have been written about servant leadership and its attributes, the focus of this article is on Barbuto and Wheeler's (2006) five servant leadership dimensions, namely altruistic calling, emotional healing, wisdom, persuasive mapping and organisational stewardship, and an exploration of how the aforementioned are related to employee commitment, trust and innovative behaviour mediated through employee empowerment. A brief description of each of the aforementioned constructs thus follows, resulting in the formulation of hypotheses to explore the proposed relationships.

\section{Empowerment}

In order for teams to be effective, the members should be empowered and trusted, committed and given space to be innovative. The impact of empowered employees goes beyond the organisation, which ultimately results in a better society (Patterson, as cited by Van Winkle, Allen, De Vore \& Winston, 2014, p. 72), which confirms what Greenleaf (1970) noted, namely, that a leader who uses power and authority to create a better society is defined as a servant leader (Van Winkle et al., 2014, p. 72).

The empowerment of individuals in a project team context has become an important area of study as there is increasing evidence that what holds true for empowering employees in a general organisational context does not necessarily translate to a project context (Nauman et al., 2010 as cited by Tuuli, Rowlinson, Fellows \& Liu, 2012, p. 150). This research endeavoured to investigate the influence servant leadership has on empowering a project team utilising the employee empowerment assessment developed by Menon (2001, p. 166).

\section{Altruistic calling and employee empowerment}

Greenleaf (1977, as cited by Hayden, 2011, p. 23) describes altruistic calling as the conscious choice of the leader to serve others. Fry (2003, p. 112) further describes altruism in a spiritual leadership setting as 'unconditional, unselfish, loyal, and benevolent care, concern, and appreciation for both self and others'. Scott and Seglow (2007, as cited by Vaughn, 2014, p. 7) define altruism as a means to 'promote the interests of others' with Smith et al. (1983, as cited by Chin, 2011, p. 4) expanding on this and describing altruism as a 'pro-social act' towards individuals within an organisation. From the above it is apparent that altruism is the force that drives an individual to act in the service of others, without regard for their own well-being; it is not motivated by the recognition or rewards that can be had as a result of serving others. Thus, altruistic calling may therefore impact on how a project sponsor influences the project team to be inspired to achieve the objectives of the project.

According to Hannay (2009, p. 5), in order for a servant leader to be effective they will require the participation and interaction of their employees, and in order for employees to participate and interact, they need to feel empowered, that is, they need the freedom (autonomy) to be able to contribute their thoughts, opinions and recommendations in a work environment where those contributions are respected and utilised. In order for employees to work autonomously they need to feel empowered to do so; thus empowerment is about giving employees the autonomy to make the necessary decisions as to how they go about their daily tasks (Haas, 2010, as cited in Humborstad \& Perry, 2011, p. 326). In light of the above, and with respect to the project sponsor as the servant leader and the project team member as the employee, it is hypothesised that:

- Hypothesis 1: Altruistic calling will be positively related to employee perceived empowerment.

\section{Emotional healing and employee empowerment}

Barbuto and Wheeler (2006, p. 318) define emotional healing as a leader's commitment and skill in helping others recover spiritually from a trauma. They further expand and state that leaders who are skilled in emotional healing are empathic individuals and great listeners, thereby facilitating the healing process. Leaders with this emotional healing trait will create a safe environment for employees to voice both their personal and professional issues. Some scholars have argued that the ability of a leader to provide emotional healing to employees goes beyond the individual and provides the emotional stability for the organisation as a whole (Weymes, 2003, as cited in Barbuto \& Gifford, 2010, p. 6). Emotional healing has been associated with the leader's ability to really listen to their followers and that the leader is empathetic to the plight of others. An empathic leader has the ability to create an environment that is safe for their followers to express both their professional and personal issues (Barbuto \& Wheeler, 2006, p. 318). In light of the above, specifically with respect to the project sponsor (as servant leader) and project team members as employees, it may be hypothesised that:

- Hypothesis 2: Emotional healing will be positively related to employee perceived empowerment.

\section{Wisdom and employee empowerment}

Scholars have likened wisdom to notions of awareness and the astuteness of the leader to pick up cues in their environments (Barbuto \& Wheeler, 2006, p. 306). McKenna and Rooney (2005, p. 2) on the other hand summarise wisdom as being the intellect of both rational (scientific) practices as well as transcendent (tacit) processes that include imagination, intuition and creativity. Wisdom in a leader 
has also been defined as the ability of the leader to assess their environment and extract the necessary cues from the environment to make decisions based on an understanding of what the consequences would be as a result of their decisions (Barbuto \& Wheeler, 2006, cited in Hayden, 2011, p. 23). Based on the above, and with respect to the project sponsor and project team members, it is hypothesised that:

- Hypothesis 3: Wisdom will be positively related to employee perceived empowerment.

\section{Persuasive mapping and employee empowerment}

Greenleaf (1980, as cited by Russell \& Stone, 2002, p. 151) highlights persuasion as a fundamental trait of the servant leader. Persuasive mapping also enables the servant leader to identify their followers' needs as well as be able to provide the necessary information so that their followers are able to perceive the importance of their work (Chin \& Pan, 2011, as cited by Klein, 2014, p. 58). Another important aspect of persuasive mapping is that the leader's influencing ability stems from a place where they are not reliant on formal authority or legitimate power to influence their followers (Barbuto \& Wheeler, 2006, p. 307).

In order to have a lasting and effective influence over their followers, the servant leader needs to approach persuasion from a rational perspective and have the ability to identify their follower's needs. Bennis and Nanus (1997, as cited by Russell \& Stone, 2002, p. 152) state that a 'pull' leadership style will result in employees being empowered. Thus, through influencing their followers, servant leaders are ultimately persuading their team to follow their lead willingly and thus the employees are empowered to choose to follow. Greenleaf (1980, as cited in Russell \& Stone, 2002, p. 151) argues that persuasion on the part of the leader is to go out ahead of the team, to show them the way forward; followers voluntarily and willingly follow as they are empowered to do so. Considering the above, this study hypothesises that:

- Hypothesis 4: Persuasive mapping will be positively related to employee perceived empowerment.

\section{Organisational stewardship and employee empowerment}

Organisational stewardship is not only the servant leader's ability to create a sense of community within the organisation, but also includes the leader's passion for impacting positively on society as a whole (Klein, 2014, p. 3). Due to the ever growing demand on organisations to stay ahead of the game, it is becoming increasingly important for organisations to evolve and adopt innovative approaches to organisational stewardship. Stewardship encompasses empowerment and the individual 'choosing partnership over patriarchy' and 'distributing ownership and responsibility' (Block, 1993, as cited by Russell \& Stone, 2002, p. 149). By sharing and owning the responsibility for organisational stewardship, employees will feel empowered to act. In light of the above, it is hypothesised that:
- Hypothesis 5: Organisational stewardship will be positively related to employee perceived empowerment.

\section{Employee empowerment and commitment}

Team commitment has three dimensions that can be identified, namely affective commitment, which describes an employee's commitment and willingness to remain with the a team because they want to, continuance commitment, which describes the costs associated with leaving a team and results in an employee remaining with said team because they have to, and normative commitment, which refers to an employee remaining with a team because they ought to as a result of their feelings of obligation towards the team (Mahembe \& Engelbrecht, 2013, p. 1).

According to Seibert, Wang and Courtright (2011, p. 985), when an employee has feelings of autonomy and empowerment, it is probable that these feelings will result in increased commitment to the organisation. Furthermore, employee empowerment has also been associated with an increase in continuance commitment as the employee would be reluctant to leave a work environment that is empowering, since the employee may view leaving the organisation as sacrificing something of value (Meyer \& Allen, 1991, as cited by Seibert et al., 2011, p. 985). Taking into consideration the abovementioned, it is hypothesised that:

- Hypothesis 6: Project team member's perceived empowerment will be positively related to their commitment.

\section{Employee empowerment and trust}

Anantatmula (2010, p. 19) states that trust encourages project team members to work together in a collaborative manner, encourages networking amongst the team members and enables the team to innovate. Leaders demonstrate their trust in team members through their actions, such as how much the leader controls or checks up on the team's work, the level of delegation, as well as the amount of freedom the team members are given in order to participate (Barry, 2002, as cited in Redick et al., 2014, p. 24).

Trust is a key factor for leaders to establish as it enables the leader to motivate the team to accomplish both the mission and vision of the project and allows the leader to manage any conflicts that may arise that, if unresolved, could impact negatively on project performance and may prevent the team from forming a cohesive unit (Anantatmula, 2010, p. 19). Leadership style has been noted as playing a significant indirect role in forming team cohesiveness and efficacy, via trust amongst team members (Chuang et al., 2004, as cited by Fung, 2014, p. 4). Employees perceive empowerment as a sign that their leader trusts them and, in turn, the employee trusts their leader, colleagues and organisation (Henkin \& Moye, 2006, as cited in Berraies et al., 2014, p. 86). In light of the aforementioned arguments, this study hypothesises that:

- Hypothesis 7: Employees' perceived empowerment will be positively related to trust. 


\section{Employee empowerment and innovative behaviour}

Innovative behaviour, which includes creativity and servant leadership, has been cited as an important leadership construct that encourages creativity (Neubert et al., 2007, as cited by Yoshida, Sendjaya, Hirst \& Cooper, 2014, p. 2). The development of new services, which requires innovative behaviour by employees, is heavily dependent on leadership (De Jong \& Den Hartog, 2003, p. 7), and effective leadership has been credited for the presence of innovative behaviour in an organisation (Khan, Aslam \& Riaz, 2012, p. 18). According to some researchers, leadership has been noted to stimulate innovative behaviour (Kouzes \& Posner, 2002; Mumford et al., 2010, as cited by Noor \& Dzulkifli, 2013, p. 129).

Research has identified a strong relationship between employee empowerment and innovation, which encompasses both the encouragement to innovative and actual innovative behaviour (Fernandez \& Moldogaziev, 2013, p. 492). The empowering of employees is important for initiating the process of innovation as it provides the employee with the independence to act in new and creative ways that go against the normal organisational standard operating processes and procedures (Pierce \& Delbecq, 1977, as cited by Fernandez \& Moldogaziev, 2013, p. 492). In order to explore the relationship between employee empowerment and innovative behaviour in a project management context, $\mathrm{H} 8$ was formulated:

- Hypothesis 8: The employee's perceived empowerment will be positively related to their innovative behaviour.

The various relationships hypothesised between the project sponsor as the servant leader and the project team members as employees are depicted in the conceptual model in Figure 1. The above hypothesised relationships depicted in the conceptual model were explored using the methodology explained below.

\section{Method \\ Research context}

This study was conducted in a medium sized organisation that provides products and services within the fleet management industry in South Africa and surrounding African countries. The organisation was in the process of implementing an entirely new enterprise resource planning (ERP) system that was to form the foundation for the organisation's information technology (IT) solution. A critical part of the organisational strategy is to improve on and automate its business, remove redundant processes and implement key performance indicators (KPIs) set against each process in order to manage employee and supplier deliverables and service delivery to clients. The objective of the IT project is to empower its employees, clients and suppliers and increase the organisation's client base without having to increase staff overheads. The ERP system will enable the delivery of an additional six IT solutions which will utilise the ERP transactional data and processes to deliver the following: a client and supplier portal, mobility solutions, business intelligence reporting, output documentation and transactional reporting, system integration and enterprise content management. The unique organisational requirements necessitated the need for the project sponsor to have an active hands-on approach and to personally engage and work with all members of the project team in order to deliver the ERP and its additional six IT solutions to the organisation. The project team was made up of the following sub-units that are interdependent: the project sponsor, the programme manager, four IT managers, the project manager, the business analysts, the functional unit representatives comprising the

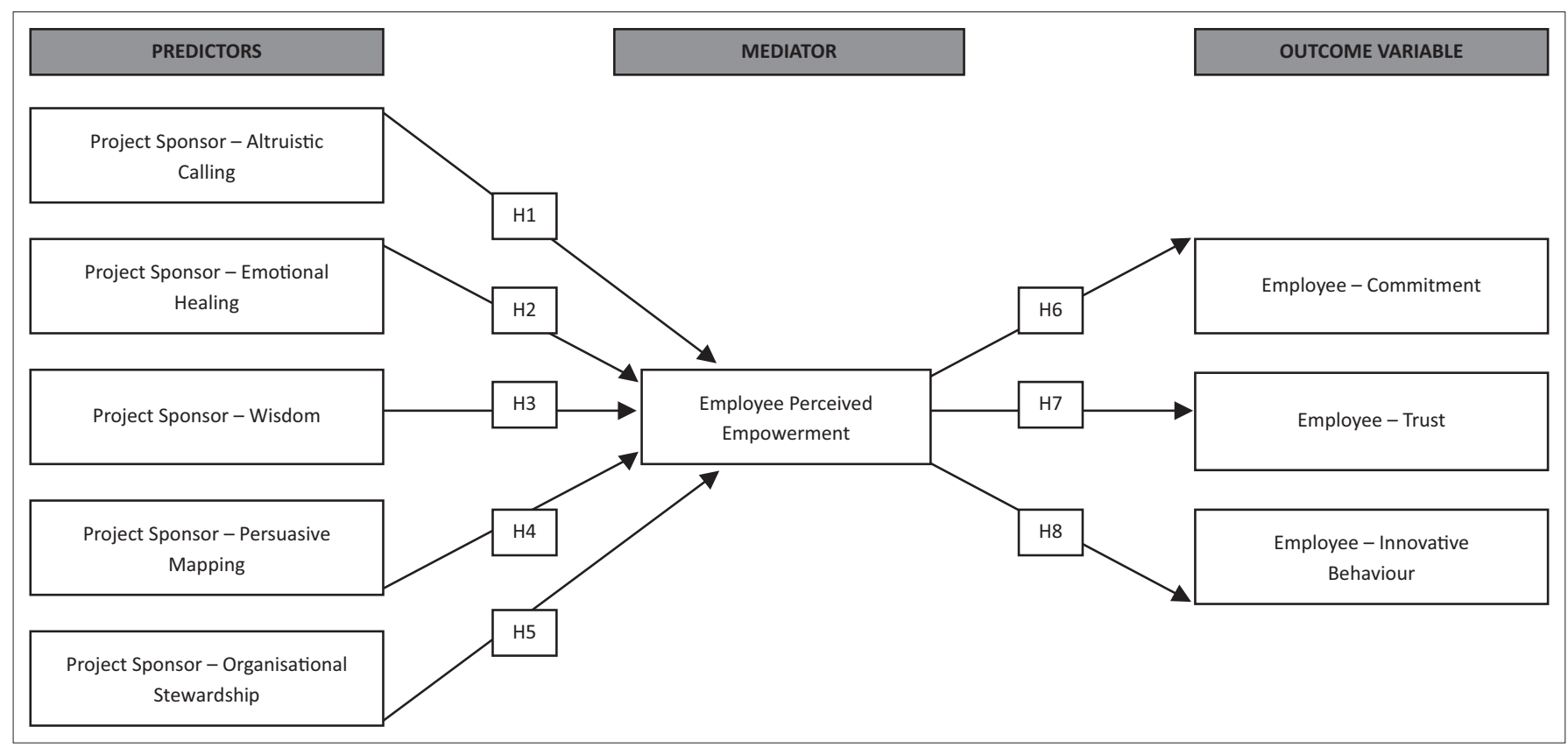

Source: Compiled by the authors

FIGURE 1: Hypothesised relationships and conceptual model. 
general managers, external consultants representing third party suppliers and developers, all of whom are required to collaborate in order to achieve the project objectives. The outcomes of empowerment, commitment, trust and innovative behaviour will be measured at these sub-unit levels, with the servant leadership traits being measured at the project sponsor's level.

\section{Sample}

Non-probability sampling, specifically purposive or judgement sampling, was used (Ivankova, Creswell \& Plano Clark, 2011, p. 178), as it ensured that the 'sample selected for the study was representative of the population in terms of the context of the study based on the researcher's specific purpose, and expert opinion regarding the population being studied'. The sample comprised third party 'supplier' employees fulfilling the role of consultants on the ERP project and project managers, as well as internal employees fulfilling the role of business analysts, general managers, IT managers, project managers and developers. The survey was conducted amongst a non-probability sample of 48 project team members from amongst a population of 257 , comprising project managers, business analysts and IT staff of the fleet management organisation.

\section{Research instruments Servant leadership measurement}

The traits of servant leadership were measured by means of the Servant Leadership Questionnaire developed by Barbuto and Wheeler (2006, as cited in Hayden, 2011, p. 22). The aforementioned authors derived five conceptually and empirically distinct servantleadership factors, namely altruistic calling, emotional healing, persuasive mapping, wisdom and organisational stewardship, analysed the five-factor construct and confirmed the revised 23-item instrument's internal consistency whose Cronbach's coefficient alphas ranged from 0.82 to 0.92 (Freeman, 2011, p. 127).

\section{Employee empowerment}

Menon's (2001) Employee Empowerment Questionnaire was used to measure employee empowerment, since it is both valid and reliable. Menon's approach to employee empowerment was an integrative psychological approach and was developed on the basis that the psychological experience of power forms the basis for feeling empowered (Menon, 2001, p. 153). Although the questionnaire had three sub-categories, namely perceived control, perceived competence and goal internalisation, the researchers selected specific questions from each sub-category on the basis that they were aligned to the purpose of this study and the hypotheses proposed.

\section{Commitment}

The Organizational Commitment Questionnaire adapted from the questionnaire developed by Tayyab and Tariq
(2001) was used to measure organisational commitment, since it was deemed reliable (0.93 alpha coefficient on the full scale, with the subscales ranging between 0.89 and 0.95 ). However, only a select number of questions were included in the combined questionnaire used for this study's purposes, namely those that could be reasonably modified to represent accurate scenarios that the project team member could face in a project environment and those aligned to the purpose of the study and the proposed hypotheses.

\section{Innovative behaviour}

Dobni (2008) developed a questionnaire to measure innovative behaviour which was associated with unidimensionality and activities and elements of innovation. Certain questions were selected from Dobni's questionnaire from amongst those that appeared under the subheading of 'organizational constituency' because they resonated with situations that could be contextualised by a project team member within the setting of the project environment.

\section{Data collection procedure}

For the purposes of this study, the group administration method was adopted, which entailed arranging an appropriate date, time and location for the respondents to complete the questionnaire. However, in instances when the respondent was not available, an electronic version of the questionnaire was emailed for completion and returned electronically.

\section{Ethical considerations}

Written permission was obtained from the organisation implementing the ERP system. Further, written permission was received from the project sponsor, who is the independent variable in this study; finally, each questionnaire incorporated a covering letter addressed to the respondents which explained the research process. Furthermore, the researcher was cognisant of the sensitivities regarding the research and the resultant impact that the research may have on the participants.

\section{Data analysis}

The Smart PLS software for structural equation modelling was used to explore the relationships in the proposed conceptual model and assess the measurement instruments. Smart PLS is a regression based technique that has emerged as a powerful approach to test causal relationships amongst variables (Chinomona \& Surujlal, 2012), even under conditions of non-normality. In addition, Smart PLS can handle complex predictive models in small to medium sample sizes and therefore fits the purpose of this study since the current study sample size is relatively small (44). PLS also generates path coefficients for the relationships modelled amongst the constructs. The significance of these coefficients was assessed using the bootstrap procedure (with 100 sub-samples), which provided the t-values for each path estimate. 
TABLE 1: Accuracy analysis statistics.

\begin{tabular}{|c|c|c|c|c|c|c|}
\hline Research constructs & Mean value & Factor loading & $R$-squared value & Cronbach's alpha value & CR value & Average variance extracted \\
\hline \multicolumn{7}{|l|}{ AC } \\
\hline AC1 & 0.864 & \multirow{4}{*}{2.977} & \multirow{4}{*}{-} & \multirow{4}{*}{0.927} & \multirow{4}{*}{0.948} & \multirow{4}{*}{0.821} \\
\hline AC2 & 0.946 & & & & & \\
\hline AC3 & 0.922 & & & & & \\
\hline AC4 & 0.89 & & & & & \\
\hline \multicolumn{7}{|l|}{ EH } \\
\hline $\mathrm{EH} 2$ & 0.954 & \multirow{3}{*}{3.841} & \multirow{3}{*}{-} & \multirow{3}{*}{0.936} & \multirow{3}{*}{0.946} & \multirow{3}{*}{0.816} \\
\hline EH3 & 0.966 & & & & & \\
\hline EH4 & 0.913 & & & & & \\
\hline \multicolumn{7}{|l|}{ w } \\
\hline W1 & 0.797 & & & & & \\
\hline W2 & 0.849 & & & & & \\
\hline W3 & 0.89 & 3.545 & - & 0.904 & 0.927 & 0.718 \\
\hline W5 & 0.831 & & & & & \\
\hline \multicolumn{7}{|l|}{ PM } \\
\hline PM1 & 0.836 & & & & & \\
\hline PM2 & 0.817 & & & & & \\
\hline PM3 & 0.784 & 3.75 & - & 0.894 & 0.918 & 0.691 \\
\hline PM4 & 0.877 & & & & & \\
\hline PM5 & 0.839 & & & & & \\
\hline \multicolumn{7}{|l|}{ os } \\
\hline OS1 & 0.652 & & & & & \\
\hline OS2 & 0.795 & & & & & \\
\hline OS3 & 0.577 & 3.636 & - & 0.793 & 0.853 & 0.541 \\
\hline OS4 & 0.861 & & & & & \\
\hline OS5 & 0.759 & & & & & \\
\hline \multicolumn{7}{|l|}{ EPE } \\
\hline EPE3 & 0.745 & 3.568 & 0.091 & 0.74 & 0.828 & 0.503 \\
\hline EPE4 & 0.777 & & & & & \\
\hline EPE5 & 0.614 & & & & & \\
\hline \multicolumn{7}{|l|}{ EC } \\
\hline EC1 & 0.702 & & & & & \\
\hline EC2 & 0.814 & & & & & \\
\hline EC3 & 0.738 & 3.841 & 0.419 & 0.833 & 0.882 & 0.6 \\
\hline EC4 & 0.813 & & & & & \\
\hline EC5 & 0.799 & & & & & \\
\hline \multicolumn{7}{|l|}{ ET } \\
\hline ET1 & 0.71 & & & & & \\
\hline ET2 & 0.803 & & & & & \\
\hline ET3 & 0.888 & 3.227 & 0.128 & 0.853 & 0.89 & 0.621 \\
\hline ET4 & 0.834 & & & & & \\
\hline ET5 & 0.693 & & & & & \\
\hline \multicolumn{7}{|l|}{ EIB } \\
\hline EIB1 & 0.814 & & & & & \\
\hline EIB2 & 0.76 & & & & & \\
\hline EIB3 & 0.833 & 3.591 & 0.464 & 0.755 & 0.832 & 0.508 \\
\hline EIB4 & 0.592 & & & & & \\
\hline EIB5 & 0.502 & & & & & \\
\hline
\end{tabular}

AC, Altruistic caring; EC, Employee commitment; EH, Emotional healing; EIB, Employee innovative behaviour; EPE, Employee perceived empowerment; ET, Employee trust; OS, Organisational sponsorship; PM, Persuasive mapping; W, Wisdom.

\section{Results}

Table 1 shows the measurement reliability, validity, mean values and the item loadings of the variables. Convergent validity was determined by assessing the values of items that loaded on their respective variables. The item loadings are expected to reach a threshold of 0.5 or higher to be acceptable. Discriminant validity was checked by ensuring that there was no significant inter-research variable cross-loadings (Chin, 1998). As reflected in Table 1, all items have loadings greater than 0.5 , with no crossloadings greater than 0.750 , whilst the t-statistics were derived from bootstrapping (100 resamples). As such, this confirms that all the measurement items converged well 
TABLE 2: Correlation between research constructs.

\begin{tabular}{|c|c|c|c|c|c|c|c|c|c|}
\hline Research construct & $A C$ & $\mathrm{EC}$ & EH & EIB & EPE & ET & OS & PM & $w$ \\
\hline$\overline{A C}$ & 1.000 & - & - & - & - & - & - & - & - \\
\hline EC & 0.549 & 1.000 & - & - & - & - & - & - & - \\
\hline $\mathrm{EH}$ & 0.637 & 0.389 & 1.000 & - & - & - & - & - & - \\
\hline EIB & 0.386 & 0.669 & 0.260 & 1.000 & - & - & - & - & - \\
\hline EPE & 0.280 & 0.658 & 0.225 & 0.690 & 1.000 & - & - & - & - \\
\hline ET & 0.297 & 0.238 & 0.161 & 0.525 & 0.385 & 1.000 & - & - & - \\
\hline OS & 0.660 & 0.387 & 0.605 & 0.175 & 0.205 & 0.169 & 1.000 & - & - \\
\hline PM & 0.542 & 0.529 & 0.526 & 0.275 & 0.386 & 0.086 & 0.750 & 1.000 & - \\
\hline W & 0.515 & 0.479 & 0.428 & 0.370 & 0.228 & 0.285 & 0.673 & 0.747 & 1.000 \\
\hline
\end{tabular}

AC, Altruistic caring; EC, Employee commitment; EH, Emotional healing; ElB, Employee innovative behaviour; EPE, Employee perceived empowerment; ET, Employee trust; OS, Organisational sponsorship; PM, Persuasive mapping; W, Wisdom.

TABLE 3: Results of structural equation model analysis.

\begin{tabular}{|c|c|c|c|c|}
\hline Hypothesised relationship & Hypothesis & Path coefficients & T-statistics & Hypothesis rejected or supported \\
\hline $\mathrm{AC} \rightarrow \mathrm{EPE}$ & $\mathrm{H} 1$ & 0.217 & 2.029 & Supported (Significant) \\
\hline $\mathrm{EH} \rightarrow \mathrm{EPE}$ & $\mathrm{H} 2$ & 0.016 & 0.065 & Supported (Insignificant) \\
\hline$W \rightarrow E P E$ & $\mathrm{H} 3$ & -0.0 .117 & 0.590 & Rejected (Insignificant) \\
\hline $\mathrm{PM} \rightarrow \mathrm{EPE}$ & $\mathrm{H} 4$ & 0.570 & 2.209 & Supported (Significant) \\
\hline $\mathrm{OS} \rightarrow \mathrm{EPE}$ & H5 & -0.297 & 2.058 & Rejected (Significant) \\
\hline $\mathrm{EPE} \rightarrow \mathrm{EC}$ & $\mathrm{H} 6$ & 0.658 & 8.765 & Supported (Significant) \\
\hline $\mathrm{EPE} \rightarrow \mathrm{ET}$ & $\mathrm{H} 7$ & 0.385 & 2.259 & Supported (Significant) \\
\hline $\mathrm{EPE} \rightarrow \mathrm{EIB}$ & $\mathrm{H} 8$ & 0.690 & 10.537 & Supported (Significant) \\
\hline
\end{tabular}

sponsorship; PM, Persuasive mapping; W, Wisdom.

on their respective constructs and therefore are acceptable measures.

According to Chin (1998), research variables should have an average variance extracted (AVE) of more than 0.5 and inter-construct correlations should be less than 0.850 for discriminant validity to exist. Table 1 reflects that all constructs exceeded these criteria, with the AVE being greater than 0.503 and the highest inter-construct correlation value being 0.750 (Table 2). The aforementioned confirms the existence of discriminant validity of the measurement used in this study.

Table 3 and Figure 2 present the results of the PLS analysis procedure on the structural model, along with the path estimates and t-values. Support for the study hypotheses, which are labelled on their corresponding paths in Figure 2, could be ascertained by examining the directionality (positive or negative) of the path coefficients and the significance of the $t$-values. The standardised path coefficients are expected to be at least 0.2 and preferably greater than 0.3 (Chin, 1998).

Although the results provide support for the proposed positive relationships between the hypotheses, Table 3 indicates that only three (H3, H4 and H5) of the posited relationships are statistically significant ( $t$-statistics value is greater than 2). Figure 2 and Table 3 provide the path coefficients for $\mathrm{H} 1, \mathrm{H} 2, \mathrm{H} 3, \mathrm{H} 4, \mathrm{H} 5, \mathrm{H} 6, \mathrm{H} 7$ and $\mathrm{H} 8$ (0.217, $0.016,-0.117,0.570,-0.297,0.658,0.385$ and 0.690 respectively). By following the formulae provided by Tenehaus, Vinzi, Chatelin and Lauro (2005), the global goodness-of-fit (GoF) statistic for the research model was calculated using the equation:
$\mathrm{GoF}=\sqrt{\mathrm{AVE} \times R^{2}}$

[Eqn 1]

The calculated global GoF is 0.38 , which exceeds the threshold of 0.36 suggested by Wetzels, OdekerkenSchröder and Van Oppen (2009); this led the researchers to conclude that the research model has a good overall fit.

In summary, this study reveals that persuasive mapping has strongest influence on employee perceived empowerment compared to altruistic caring, emotional healing, wisdom and organisational sponsorship. However, wisdom and organisational sponsorship have a negative effect on employee perceived empowerment, whilst at the same time, the relationships between wisdom and employee perceived empowerment and emotional healing and employee perceived empowerment relationships are insignificant. On the other hand, employee perceived empowerment has a stronger effect on employee innovative behaviour, when compared to employee trust and employee commitment.

The results also show that persuasive mapping has the strongest impact on employee innovative behaviour, followed by employee commitment and lastly, employee trust via employee perceived empowerment. By implication, the findings indicate that the more the employers or sponsors use a persuasive approach in their leadership, the more the employees will feel empowered and consequently the more willing they are to adopt innovative behaviour.

\section{Discussion of the findings}

Haas (2010, as cited in Humborstad \& Perry, 2011, p. 326) argues that autonomy comes about when employees are 


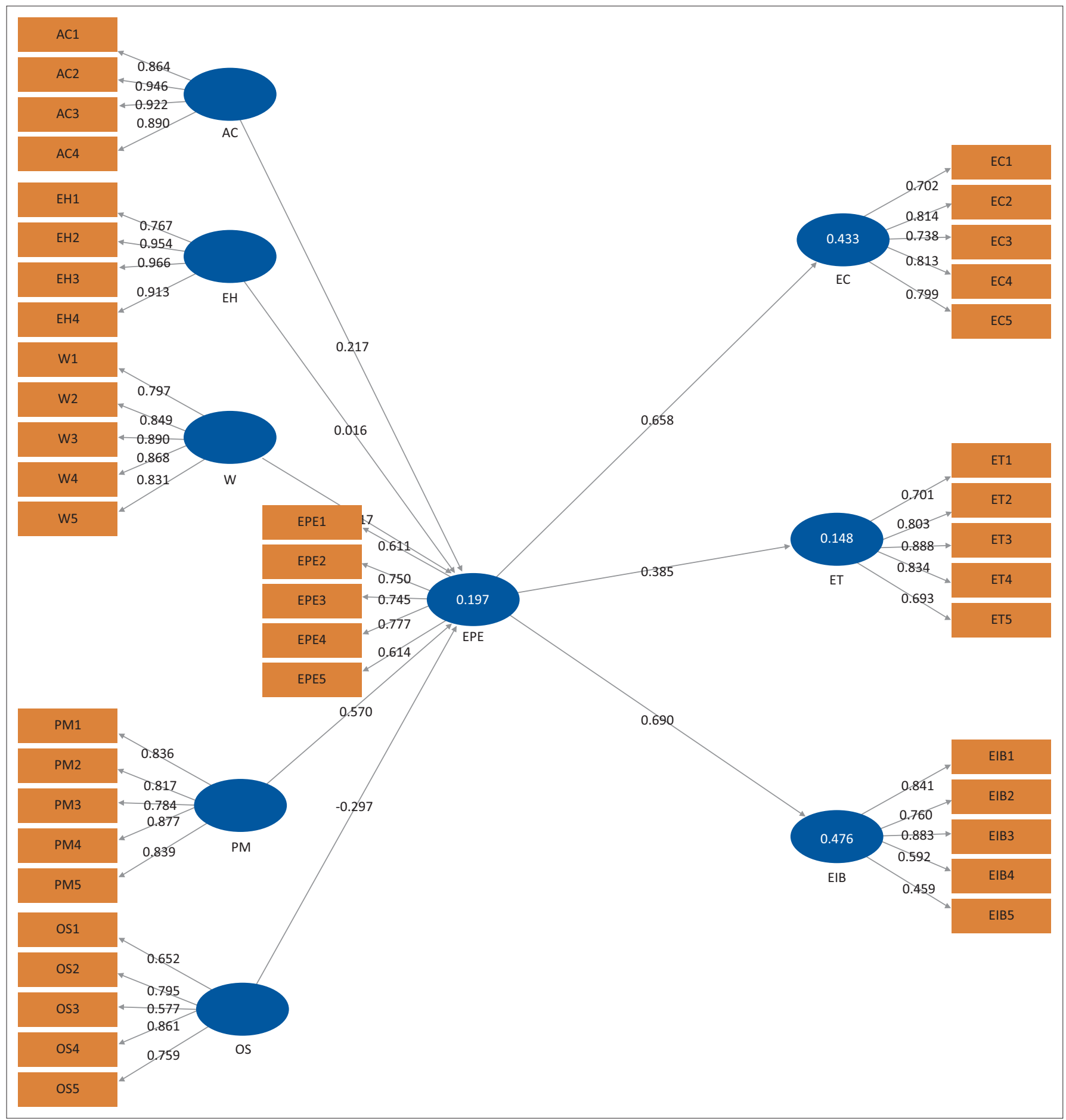

Source: Compiled by the authors

AC, Altruistic caring; EC, Employee commitment; EH, Emotional healing; EIB, Employee innovative behaviour; EPE, Employee perceived empowerment; ET, Employee trust; OS, Organisational sponsorship; PM, Persuasive mapping; W, Wisdom.

FIGURE 2: Measurement and structural model results.

empowered, by their leader, to be self-sufficient in conducting their day-to-day activities as they see fit. This study supports that the aforementioned assertion is equally applicable in a project environment as well, since the altruistic calling in a project sponsor is positively related to the project team's sense of employee perceived empowerment (H1).

Although Barbuto and Wheeler (2006, p. 318) highlight that the servant leadership trait of emotional healing would empower employees to express their personal and professional issues, this study did not support the postulation made by the researcher, and the results were insignificant (H2). Furthermore, although Manz (1998, as cited in Russell \& Stone, 2002, p. 152) states that if a leader is wise, they will guide and support their followers by empowering them to lead themselves, this view was also not supported in this study, since the servant leadership trait of 'wisdom' did not result in an empowered project team (H3). According 
to Hannay $(2009$, p. 5), if employees feel that their leader is omnipotent and unquestioningly correct in all matters, it is unlikely then that they will feel empowered to provide an opinion or challenge their leader's position. This could be the case in this study, where the project team members are intimidated by the project sponsor's wisdom and therefore do not feel empowered to offer their opinion or object to or challenge the project sponsor. The project environment may also not lend itself to the project team members feeling empowered, due to the circumstances of the project; the project sponsor may be taking unilateral decisions, as a result of their assumed wisdom, which sees them not consulting with or getting feedback from the project team members, which may create a sense of disempowerment amongst the project team members. These unilateral decisions maybe as a result of the constraints and pressures experienced within a project environment where time is of the essence.

According to some existing research, persuasive mapping involves empowering employees to make their own decisions; thus, when employees follow, they do so willingly (Bennis \& Nanus, 1997, as cited in Russell \& Stone, 2002, p. 152). This study supports the aforementioned, in that the results show that persuasive mapping of the project sponsor results in the project team feeling empowered ( $\mathrm{H} 4)$.

In order for organisational stewardship to be adopted, a leader needs to empower their followers so that they freely choose to become stewards themselves (Fairholm, 1997, 1998, as cited in Russell \& Stone, 2002, p. 149). The leader empowers followers by creating a partnership with them so that organisational stewardship is a responsibility that is jointly owned by all parties (Block, 1993, as cited in Russell \& Stone, 2002, p. 149). The results of this study do not support the aforementioned views, in that it was evident that organisational stewardship in the project sponsor did not result in the project team members being empowered (H5).

Research shows that when employees experience a sense of empowerment it translates into an increase in the employee's commitment to the organisation (Seibert et al., 2011, p. 985). Additionally, an increase in continuance commitment ensues when employees feel empowered; this continuance commitment is accounted for by the employee experiencing a sense of loss of something they hold as valuable should they leave the organisation (Meyer \& Allen, 1991, as cited by Seibert et al., 2011, p. 985). This study further supports the aforementioned views, in that the project team members felt empowered, which translated into them being committed to the project (H6). Some studies have also argued that when employees feel empowered they perceive it as a sign that their leader trusts them, which translates into the employees then trusting their leader, their colleagues, as well as the organisation (Henkin \& Moye, 2006, as cited in Berraies et al., 2014 , p. 86). The aforementioned seems to true in a project management environment, since, in this study, the project team members felt empowered and this translated into a positive relationship with trust amongst the project team members (H7). Recent studies have acknowledged the strong relationship that exists between employee empowerment and employee innovativeness (Fernandez \& Moldogaziev, 2013, p. 492), and empowerment has been identified as a key initiator of the innovation process within employees, since through empowerment, employees have autonomy to act in ways that are novel and unique and which go against the existing status quo (Pierce \& Delbecq, 1977, as cited by Fernandez \& Moldogaziev, 2013, p. 492). This study also supports the aforementioned views in that there is a strong relationship between the project team's perception of empowerment and their innovative behaviour (H8).

\section{Practical implications}

The findings provide fruitful implications to both practitioners and academicians. On the academic side, this study contributes to the leadership literature by systematically exploring the impact of altruistic caring, emotional healing, wisdom, persuasive mapping and organisational sponsorship on employee commitment, employee trust and employee innovative behaviour through the mediating role of employee perceived empowerment in a project management context in South Africa. In particular, the findings provide tentative support for the proposition that altruistic caring, emotional healing and persuasive mapping should be recognised as significant 'instruments' to influence employee innovative behaviour, commitment and trust via employee empowerment. On the practitioners' side, the important influential role of persuasive mapping and altruistic caring on employee empowerment and consequently on employee innovative behaviour, commitment and trust is highlighted. This study points out that project leaders should adopt and exhibit persuasive mapping and altruistic caring leadership qualities, in order to make their employees feel empowered and consequently stimulate their innovative behaviour, commitment and trust.

\section{Limitations}

This study, albeit exploratory, was conducted in one organisation and one project. For greater generalisation, a repeated study in different organisational contexts is necessary. A further limitation is the geographic spread of the study, which only concentrated on a single province (out of nine) in South Africa. Moreover, the study was limited to only 44 participants in one organisation.

\section{Recommendations}

The limitations of this research can also be viewed as avenues for future studies. An important limitation is the geographic spread of the study since it only concentrated on a single province (out of the nine South African provinces). Subsequent research should contemplate replicating this study in other provinces of South Africa or even other African countries for comparison. Moreover, since the study was limited to only 44 participants in one organisation in South Africa, future studies should consider expanding 
the data collection to include a larger, more representative sample. Finally, further research could also investigate the effects of other servant leadership dimensions on employee empowerment. Such an expanded model may likely yield more interesting research findings and insights of value to both academics and practitioners alike.

\section{Conclusion}

The purpose of this study was to determine the influence of altruistic caring, emotional healing, wisdom, persuasive mapping and organisational sponsorship on employee commitment, employee trust and employee innovative behaviour through the mediating role of employee perceived empowerment. In particular, eight hypotheses were postulated and tested using data from 44 respondents in South Africa. The empirical results supported three of the research hypotheses and five in a significant way. The findings indicate that persuasive mapping has the strongest impact on employee innovative behaviour followed by employee commitment and lastly employee trust via employee perceived empowerment when compared to the influence of altruistic caring, wisdom, emotional healing and organisational sponsorship on the same.

\section{Acknowledgements \\ Competing interests}

The authors declare that they have no financial or personal relationships that may have inappropriately influenced them in writing this article.

\section{Authors' contributions}

This article was extracted from the MBA dissertation of C.L.K. (Regenesys Business School) whose study was supervised by K.G. (University of KwaZulu-Natal). The article was primarily written by K.G. K.G. advised C.K. on the data analysis and interpretation of the findings and writeup thereof.

\section{References}

Anantatmula, V.S. (2010). Project manager leadership role in improving project performance. Engineering Management Journal, 22(1), 13-22. http://dx.doi.org /10.1080/10429247.2010.11431849

Barbuto, J.E., \& Gifford, G.T. (2010). Examining gender differences of servant leadership: An analysis of the agentic and communal properties of the servant leadership questionnaire. Journal of Leadership Education, 9(2), 1-21.

Barbuto, J.E., \& Wheeler, D.W. (2006). Scale development and construct clarification of servant leadership. Group \& Organization Management, 31, 300-326. http:// dx.doi.org/10.1177/1059601106287091

Berraies, S., Chaher, M., \& Ben Yahia, K. (2014). Employee empowerment and its importance for trust, innovation and organizational performance. Business Management and Strategy, 5(2), 82-103. http://dx.doi.org/10.5296/bms. Management
v5 6558

Chin, Y.-C. (1998). Altruistic leadership, employee engagement and financial performance. Sacramento, CA: California State University.

Chin, Y.-C., 2011, Altristic Leadership, Employee Engagement and Financial Performance, Sacramento, California State University.

Chinomona, R., \& Surujlal, B. (2012). Antecedents of gambling risk taking behaviours in South Africa. African Journal of Physical, Health Education, Recreation and Dance, 1(1), 50-63.

Clarke, N. (2012). Leadership in projects: What we know from the literature and new insights. Team Performance Management: An International Journal, 18(3/4), 128148. http://dx.doi.org/10.1108/13527591211241042
De Jong, J., \& Den Hartog, D. (2003). Leadership as a determinant of innovative behaviour: A conceptual framework, The Hague, The Netherlands: Scientific Analysis of Entrepreneurship and SMEs.

Dobni, C.B. (2008). Measuring innovation culture in organizations: The development of a generalized innovation culture construct using exploratory factor analysis. European Journal of Innovation Management, 11, 539-559. http://dx.doi. org/10.1108/14601060810911156

Fernandez, S., \& Moldogaziev, T. (2013). Employee empowerment, employee attitudes, and performance: Testing a causal model. Public Administration Review, 73, 490-506. http://dx.doi.org/10.1111/puar.12049

Freeman, G.T. (2011). Spiritual and servant leadership: A conceptual model and research proposal. Emerging Leadership Journeys, 4(1), 120-140.

Fry, L.W. (2003). Toward a theory of spiritual leadership. The Leadership Quarterly, 14(6), 693-727. http://dx.doi.org/10.1016/j.leaqua.2003.09.001

Fung, H.-P. (2014). Relationships among team trust, team cohesion, team satisfaction and project team effectiveness as perceived by project managers in Malaysia. International Journal of Business, Economics and Management, 1(1), 1-15.

Greenleaf, R.K. (1970). Who is the servant leader? In The servant as leader. Retrieved September 4, 2015, from https://greenleaf.org.

Hannay, M. (2009). The cross-cultural leader: The application of servant leadership theory in the international context. Journal of International Business and Cultural Studies, 1, 1-12.

Hayden, R.W. (2011). Greenleaf's 'best test' of servant leadership: A multilevel analysis. Lincoln, NE: Faculty Publications: Agricultural Leadership, Education \& Communication Department.

Humborstad, S.I.W., \& Perry, C. (2011). Employee empowerment, job satisfaction and organizational commitment: An in-depth empirical investigation. Chinese Management Studies, 5, 325-344. http://dx.doi. org/10.1108/17506141111163390

Ivankova, N.V., Creswell, J.W., \& Plano Clark, V.L. (2011). First steps in research. (9th edn.). Pretoria, South Africa: Van Schaik.

Khan, M.J., Aslam, N., \& Riaz, M.N. (2012). Leadership styles as predictors of innovative work behaviour. Pakistan Journal of Social and Clinical Psychology, 10(1), 17-22.

Kilkelly, E. (2011). Using training and development to recover failing projects. Human Resource Management International Digest, 19(4), 3-6. http://dx.doi. org/10.1108/09670731111140649

Klein, N.D. (2014). The relationship between servant leadership and employee engagement: The mediating roles of trust and fit. Omaha, NE: Creighton University.

Kouzes, J.M., \& Posner, B.Z. (2002). The leadership practices inventory: Theory and evidence behind the five practices of exemplary leaders. Retrieved February 12, 2015, from http://www.Leadershipchallenge.com

Leyva, J.A.M., \& Matović, V. (2011). Project management practices at the front-end of management consulting projects. Umeå, Sweden: Umeå School of Business.

Mahembe, B., \& Engelbrecht, A.S. (2013). The relationship between servant leadership, affective team commitment and team effectiveness. SA Journal of Human Resource Management, 11(1), 1-10. http://dx.doi.org/10.4102/sajhrm. v11i1.495

McKenna, B., \& Rooney, D. (2005). Wisdom management: Tensions between theory and practice in practice. Queensland, Australia: University of Queensland.

Menon, S.T. (2001). Employee empowerment: An integrative psychological approach. Oxford and Malden, UK: Blackwell Publishers.

Noor, H.M., \& Dzulkifli, B. (2013). Assessing leadership practices, organizationa climate and its effect towards innovative work behaviour in R\&D. International Journal of Social Science and Humanity, 3(2), 129-133. http://dx.doi.org/10.7763/ IJSSH.2013.V3.211

Parris, D.L., \& Peachey, J.W. (2013). A systematic literature review of servant leadership theory in organizational contexts. Journal of Business Ethics, 113, 377-393. http:// dx.doi.org/10.1007/s10551-012-1322-6

Redick, A., Reyna, I., Schaffer, C., \& Toomey, D. (2014). Four-factor model for effective project leadership competency. Journal of IT and Economic Development, 5(1), 21-35.

Riaz, A., Tahir, M.M., \& Noor, A. (2013). Leadership is vital for project managers to achieve project efficacy. Research Journal of Recent Sciences, 2(6), 99-102.

Rickards, T., \& Moger, S. (2000). Creative leadership processes in project team development: An alternative to Tuckman's stage model. British Journal of Management, 11, 273-283. http://dx.doi.org/10.1111/1467-8551.00173

Russell, R.F., \& Stone, A.G. (2002). A review of servant leadership attributes: Developing a practical model. Leadership \& Organization Development Journal, 23(3), 145-157. http://dx.doi.org/10.1108/01437730210424

Seibert, S.E., Wang, G., \& Courtright, S.H. (2011). Antecedents and consequences of psychological and team empowerment in organizations: A meta-analytic review. Journal of Applied Psychology, 96(5), 981-1003. PMID: 21443317, http://dx.doi. org/10.1037/a0022676

Stone, A.G., \& Patterson, K. (2005). The history of leadership focus. Virginia Beach, VA: Regent University.

Tayyab, S., \& Tariq, N. (2001). Development of an indigenous organisational commitment questionnaire. Pakistan Journal of Psychological Research, 16(1-2), 31-45. 
Tenehaus, M., Vinzi, E., Chatelin, Y.M., \& Lauro, C. (2005). PLS path modeling. Computational Statistics and Data Analysis, 48, 159-205. http://dx.doi. org/10.1016/j.csda.2004.03.005

Thompson, K.N. (2010). Servant leadership: An effective model for project management, Minneapolis, MN: Capella University.

Tuuli, M.M., Rowlinson, S., Fellows, R., \& Liu, A.M.M. (2012). Empowering the project team: Impact of leadership style and team context. Team Performance Management: An International Journal, 18(3/4), 149-175. http://dx.doi. org/10.1108/13527591211241006

Van Dierendonck, D. (2010). Servant leadership: A review and synthesis. Journal of Management, 37, 1228-1261. http://dx.doi.org/10.1177/0149206310380462

Van Winkle, B., Allen, S., DeVore, D., \& Winston, B. (2014). The relationship between the servant leader behaviours of immediate supervisors and follower's perceptions of being empowered in the context of small business. Journal of Leadership Education, 13(3), 70-82.
Vaughn, E.C.R. (2014). Assessing altruistic behaviour, burnout, and wellness outcomes of entry level live-in and live on residence life professionals. Louisiana: Louisiana State University.

Walumbwa, F.O., Hartnell, C.A., \& Oke, A. (2010). Servant leadership, procedural justice climate, service climate, employee attitudes, and organizational citizenship behavior: A cross-level investigation. Journal of Applied Psychology, 95, 517-529. PMID: 20476830, http://dx.doi.org/10.1037/a0018867

Wetzels, M., Odekerken-Schröder, G., \& Van Oppen, C. (2009). Using PLS modelling to assess hierarchical construct models: Guidelines and empirical illustration. MIS Quarterly, 33(1), 177-195.

Yoshida, D.T., Sendjaya, S., Hirst, G., \& Cooper, B. (2014). Does servant leadership foster creativity and innovation? A multi-level mediation study of identification and prototypicality. Journal of Business Research, 67, 1395-1404. http://dx.doi. org/10.1016/j.jbusres.2013.08.013

Yukl, G. (2013). Leadership in organisations. (8th edn.). Essex, UK: Pearson Education Limited. 